\title{
Access, Parentalism and Justice: Epistemological Reflections on Integration and Inclusion in Education
}

\author{
Kai Horsthemke \\ Bildungsphilosophie und Systematische Pädagogik, KU Eichstätt-Ingolstadt, Germany \\ Email: kai.horsthemke@gmail.com; Kai.Horsthemke@wits.ac.za
}

\begin{abstract}
Inclusion in education and upbringing is understood as belonging, as the opposite of exclusion. How do people with cognitive and physical impairments learn, and how do they acquire knowledge? Access to schools and other institutions of learning is not the same as access to knowledge. In addition, opportunities for learning and the imparting and grasping of knowledge differ from person to person. Nobody can be included everywhere or demand unqualified access. It would be desirable but it is not always possible to be able to determine where and how one is to be included. In cases of limited autonomy there has to be a kind of selection and control of knowledge. This means the young and the cognitively impaired do not have unconstrained access to knowledge. Educators and parents are responsible for selecting and controlling knowledge for the young and the cognitively impaired. How this can be done justly? How ought one to deal with the knowledge claims and the epistemic and cognitive abilities of those with relevant deficiencies? Under what circumstances can one speak of knowledge here? And what would be the basis for inclusion within a knowledge community?
\end{abstract}

Keywords: Context-sensitive realism; epistemological access; epistemic justice, epistemic paternalism, inclusive education, social epistemology.

\section{Introduction: Justice, Integration and Inclusion}

John Rawls's theory has probably been the most influential contribution to the discussion of justice during the last 50 years. Rawls has argued that the limited scope of 'justice as fairness' and of equality can be accounted for in terms of a hypothetical contract. This contract is struck by self-interested beings in what Rawls calls 'the original position' under the 'veil of ignorance'. Ignorant of what their future life, prospects and capacities, and so on, will be, they select principles of justice to ensure for them fair and equal consideration and treatment (Rawls, 1971). Rawls is aware of the fact that his theory

fails to embrace all moral relationships, since it would seem to include only our relation with other persons and to leave out of account how we are to conduct ourselves towards animals and the rest of nature. I do not contend that the contract notion offers a way to approach these questions which are certainly of the first importance, and I shall have to put them aside. (Rawls, 1971: 17)

If these questions are really of prime importance, one might argue that any theory that fails to give them due consideration must either be abandoned or amended. Alternatively, one might examine the reasons for excluding animals from considerations of justice and equality, assess their validity, and inquire into the theory's (undesirable) implications. One of these is that it excludes all those who are unable, for whatever reasons, to enter into contractual agreements and arrangements, i.e. (amongst others) individuals with disabilities and foreign nationals who have escaped illiberal, oppressive and lifethreatening situations at home (see also Gutmann, 2009). Any theory that links considerations of justice (and indeed of morality) too tightly with considerations of mutual advantage within the nation-state as the basic unit of analysis is likely to exclude not only nonhuman animals and people with mental and physical handicaps but also those who happen to originate in a place outside of the specific nation-state or supranational configuration of states. 'Today', Martha Nussbaum notes,

when the issue of justice for people with disabilities is prominent on the agenda of every decent society, the omission of all of them from participation in the situation of basic political choice 
looks problematic, given the evident capacity of many if not most of them for choice; and their omission from the group of persons for whom society's most basic principles are chosen is more problematic still. Even if their interests can be taken into account derivatively or at a later stage, we naturally wonder why this postponement is necessary, and whether it is not likely to affect the fully equal treatment of such citizens - even if it is not in and of itself a form of unequal treatment. (Nussbaum, 2006: 18)

Rawls acknowledges that these are problems for his contractarian position and that 'justice as fairness may fail' with regard to the consideration and treatment of those with disabilities and those who are not members of the species Homo sapiens (Rawls, 1996: 21). Much of his later work is devoted to attempts to address the problem for contractarianism constituted by foreign nationals, which he deems solvable (see also Nussbaum 2006: 3).

The ideas of inclusion and nonexclusion have received sporadic attention in post-Rawlsian social and educational philosophy. In response to Rawls's approach, Nussbaum has called for a theory of justice that offers a more inclusive account of social cooperation, one that values the diverse capabilities of individuals. She builds on Rawls's work, in order to explore the ramifications of a theory of justice for the mentally and physically disabled, foreign nationals, and nonhuman animals.

One of the basic principles in Amy Gutmann's theory of democratic education is the principle of nonexclusion:

In its application to primary schooling, whose social purpose is to develop democratic character in all its citizens, the principle of nondiscrimination becomes a principle of nonexclusion: no educable child may be excluded from an education adequate to participating in the processes that structure choice among good lives. Stated so abstractly, the principle of nonexclusion provides a necessary but not a sufficient standard of democratic distribution with regard to primary schooling. (Gutmann, 1987: 127)

The ideas of integration and inclusion have gained additional currency with the refugee situation presently challenging Europe and the EU. In what ways, if any, is inclusion different from integration? Inclusion is commonly understood as a reform programme for deep-seated and far-reaching transformation of society as a whole and, in particular, of the school system as such, whereas integration refers to the incorporation or absorption of certain groups of people into society and, in particular, of certain groups of learners into the existing school system, which remains essentially untransformed (see Stojanov, 2015: 3). It should be clear that both integration and inclusion apply, in principle, to the accommodation both of foreign nationals (and refugees) and of impaired persons. The current concern in many European countries is whether an inclusive (as contrasted with integrative) approach to the refugee challenge would not involve some kind of abandonment (or disintegration) of national identity and constitute a threat to the social fabric as a whole. (Indeed, there appears to be a tendency to treat integration as the preferred process of dealing with refugees and inclusion as the more desirable way of accommodating persons with disability.) This problem, and its educational implications, surely merits thorough investigation - which this paper, however, will not seek to provide. Instead, I will focus on the demands imposed by the accommodation of those with disabilities and only occasionally refer to foreign nationals and refugees, by way of illustration and contrast.

Further questions are: Does taking educational justice seriously entail inclusion or only integration? Could inclusion conceivably violate the norms of educational justice? ${ }^{1}$ To what extent, if any, do those with cognitive disabilities benefit from inclusive educational practices? And what, if anything, does inclusion offer those without relevant disabilities (Merz-Atalik, 2015; the notion of 'relevant' is significant here, because everyone has strengths, as well as weaknesses that arguably require some degree of attention ${ }^{2}$ )? A quick response to the last question might be that, at the very least, those without pertinent handicaps are likely to develop a greater sensitivity towards those who are so disabled and to increase their ability to take a pro-active role in a world of difference, diversity and

\footnotetext{
${ }^{1}$ In this regard, Krassimir Stojanov examines the different responses provided in terms of distributive justice, participatory justice and recognitory justice (Stojanov, 2015; see also Stojanov, 2011: 27-45).

${ }^{2}$ Nussbaum concurs: '... it would be progress of we could acknowledge that there really is no such thing as "the normal child": instead, there are children, with varying capabilities and varying impediments, all of whom need individualized attention as their capabilities are developed' (Nussbaum, 2006: 210).
} 
heterogeneity ${ }^{3}$. Nussbaum, referring to education and inclusion in particular, claims that the practice of 'mainstreaming' children with disabilities

can be defended on grounds of the benefit to the mentally disabled child, who will be given more incentives to develop cognitively and who may be less likely to be stigmatised as type apart. It can also be defended because of the benefit it offers to so-called normal children, who learn about humanity and its diversity by being in a classroom with a child who has unusual impairments. They learn to think for themselves, their own weaknesses, and the variety of human capability, in a new way ... (Nussbaum 2006: 205-206)

The ethical dimension of integration and inclusion is only one of several areas of possible philosophical investigation. My concern here is less with the ethical than with the epistemological dimension, which nonetheless retains a bearing on the question of educational justice. This article attempts to provide an analysis of the following three epistemological aspects ${ }^{4}$, with regard to the notion of inclusion and the conception of justice within education, in terms of both the connections and tensions between them:

- epistemological access (Morrow, 2007; see also Lotz-Sisitka, 2009; Bekker, 2013, Walton, 2013, Walton and Bekker, 2013),

- epistemic parentalism (following Goldman's notion of epistemic paternalism; Goldman, 1992), and

- epistemic justice (Fricker, 2007).

\section{Epistemological Access}

There is a tendency to associate inclusive education with learners with various kinds of disability, especially those with 'special educational needs' (Walton and Bekker, 2013: 442). This is a rather problematic label. As Elizabeth Walton and Tanya Bekker have explained, a learner diagnosed with cerebral palsy (which is commonly identified as a 'special need') may require considerably less help from her teacher than a young person who heads a household (which is not usually considered a 'special need'; p. 458). Less narrowly conceived, however, inclusive education targets the various ways in which marginalisation and disadvantage, generally, occur in educational contexts and situations - in other words, all kinds of exclusion from those opportunities that ought to characterise access to learning. Amongst other things, inclusive pedagogy might be understood as providing learners with epistemological access. In other words, and importantly, inclusive education is 'an issue of how epistemological access is enabled or constrained by the pedagogical choices we make' (ibid.). 'In inclusive education discourse', according to Walton and Bekker, "exclusion" is used to describe not only the physical non-presence of children, but also the variety of factors that impede full and fair access to and participation in school activities': that is, 'access to the curriculum, learning and teacher attention, access to peer and social interactions, ... and access to school resources, extra-curricular activities and participation in school traditions' (p. 450).

The term 'epistemological access' was first coined by Wally Morrow (2009: iv), the late South African educational philosopher who played a significant role in post-apartheid educational reform. 'Starting from the idea that teaching is conceptually linked to the idea of access', Morrow argues that

there are two kinds of access - formal and epistemological - not commonly distinguished from each other. Formal access is a matter of access to the institutions of learning, and it depends on factors such as admission rules, personal finances, and so on; epistemological access, on the other hand, is access to [the goods that institutions distribute to those it formally admits and, as the main good distributed by educational institutions, to] knowledge [which must be understood here as encompassing all kinds of practical and theoretical knowledge]. While formal access is important in the light of our history of unjustifiable institutional exclusions, epistemological access is what the game is about. One way of characterising teaching is to say that it is the practice of enabling epistemological access. (Morrow, 2007: 2; see also p. 8, note 6, and p. 39).

\footnotetext{
${ }^{3}$ An interesting question in this regard is whether heterogeneity is merely a state in the absence of an ideal state (i.e. homogeneity) or whether it is desirable in and for itself. I owe this point to Joachim Thomas.

${ }^{4}$ To be more precise, these are ideas within the fairly new field of social epistemology, understood here as concerned with the interpersonal and social practices and norms that influence and guide the search for knowledge.
} 
It follows that the question, 'Epistemological access for whom?' (Walton and Bekker, 2013: 443), appears to receive the rather uninteresting answer, 'Everyone who is educable'. But this by no means renders the concept superfluous. Given that education and classrooms, in particular, are increasingly characterised by diversity and heterogeneity of learners (commonly with vastly different features, competences, learning needs and learning barriers), it is clear that a 'one-size-fits-all' approach does not (any longer) meet current challenges (ibid.; see also Walton, 2013: 508). This will also have a bearing on the breadth and depth of the access in question. On the other hand, responsive educators also need to protect themselves from pedagogical paralysis. If the uniqueness of learners necessitates respectively unique teaching strategies, then an over-emphasis of the individual could soon lead to a culture of overemphasising difference. It could be argued that it is not so much a matter of diversity in general but rather of emphasis on pedagogically relevant differences, that is, of judging when and to what extent individual and group differences are pedagogically significant, of planning lessons that are meant to provide access for all, and so on. The quality of pedagogy, that is, how educators work with knowledge, can be seen either as promoting or as preventing access. Heila Lotz-Sisitka (2009), building on Morrow's ideas and on the basis of several case studies, lists several ways in which teaching practice can constrain epistemological access:

- through teacher's failure to bridge the divide between the concrete and the abstract, or between everyday knowledge and school knowledge;

- through teacher's failure to interpret the demands of setting curricular standards and subsequent limitation of the scope and level of access in relation to these standards;

- through reliance on teacher knowledge only, which may in itself be limited, and subsequent limitation of the scope and depth of access to new knowledge; and

- through inadequate feedback on tasks, and subsequent failure to enable learners to deepen their understanding or address misconceptions (see also Walton \& Bekker, 2013: 452).

In the remainder of this section, I discuss three problems I have identified. First, it would appear that a substantial portion of the literature on inclusion understands epistemological access in constructivist terms, i.e. in terms of learners being 'active participants in the construction of their knowledge' (Bekker, 2013: 467). Thus, Bekker writes:

Knowledge is frequently presented as contested (in other words, it is not presented as a fixed body of information, but rather as being constructed; contrasting points of view or interpretations and potentially conflicting forms of knowledge are discussed) instead of as universally accepted by all (that is, as a one-dimensional body of truth)..$^{5}$ (p. 476)

What is missing in the pertinent literature is an account, let alone a critical analysis, of the concept of knowledge. An examination of this idea may well demonstrate that the conceptualisation of constructivism as an epistemology (and perhaps even as a pedagogy and as a learning theory) is highly problematic $^{6}$. The common assertion that knowledge is 'contested' seems to draw its strength entirely from this lack of definition and conceptual clarity. Once an account of different uses of the term 'knowledge' and circumspect definitions is furnished, much of the putative basis for 'contestation' will have been eroded. By the time students have completed their undergraduate teacher training, many

\footnotetext{
${ }^{5}$ The idea is that substantive conversation is needed in multicultural or intercultural contexts, where knowledge is seen as emanating from specific social and cultural histories rather than as 'fixed'. From an inclusive education perspective Michel Foucault's critique of epistemological hegemony and his analysis of how knowledge and truth are always part of systems of power are considered significant (Bekker; personal communication):

Each society has its own regime of truth, its "general politics" of truth: that is, the types of discourse which it accepts and makes function as true; the mechanisms and instances which enable one to distinguish true and false statements, the means by which each is sanctioned; the techniques and procedures accorded value in the acquisition of truth; the status of those who are charged with saying what counts as true. (Foucault, 1984: 73)

At least two concerns arise in this regard. The ideas of 'regimes of truth' and '"general politics" of truth' not only indicate a category mistake (in treating epistemological matters as necessarily inseparable from matters of social justice), but they are also dangerously close to relativism about truth.

${ }^{6}$ The most significant problems are posed by relativism (both about knowledge and about truth) and by the difficulty to distinguish between knowledge and mere belief, between science and non-science (especially dogma and superstition).
} 
have been thoroughly indoctrinated with constructivism. (On the purported significance and relevance of constructivist theory in today's classrooms, see - for example - Delanty, 1997; Duffy and Cunningham 1996; Potter, 1996; Richardson, 2003; Von Glasersfeld, 2000; Windschitl, 1999 and 2002.) It is generally assumed that it is only constructivism that provides a compelling account of active, student centered teaching and learning, and that rival pedagogies and learning theories err in significant respects. According to Duffy and Cunningham, and also Windschitl (Duffy and Cunningham, 1996; Windschitl, 1999 and 2002), one of the most difficult underpinnings of constructivism for educators to embrace is that there are no universal truths and that constructivism by its very nature is not compatible with more objective forms of knowing. No wonder, one might respond - since this can only be apprehended as a 'universal truth' itself, or in terms of an 'objective form of knowing', respectively. It would appear then that in an important respect constructivism is self-undermining: either there are no universal truths (or objective forms of knowing), except this particular one; or the statement in question does not itself constitute a universal truth, or objective form of knowing.

There is clearly a grain of truth in constructivism. Some facts are socially constructed, the results of human description and designation - like pass grades in tests or exams, codes of ethics, laws, speed limits, standards of etiquette, culinary recipes, and so on: contingent facts that emanate from our social practices. Constructivism errs, however, in saying that all facts, including historical and scientific facts, are human constructs. As a pedagogy, I suggest, constructivism has two major, related shortcomings. It degrades a fundamental educational task - that of transmission of knowledge. Furthermore, like postmodernism, constructivism is not only misleading but also potentially dangerous, in that it gives people (educators as well as learners) a false sense of empowerment and authority. Contrary to what their advocates have contended, neither approach is emancipatory. In fact, both as a pedagogy and as a learning theory, constructivism is likely to be disturbingly disempowering. The failure of outcomes-based education in most parts of the world, with its devaluation of subject-based knowledge, knowledge developed in the past and of knowledge for its own sake, is testimony to the plausibility of this judgement. ${ }^{7}$ It should be noted that the logic of neither inclusion nor epistemological access requires adoption of a constructivist epistemology.

Moreover, there is a tendency in the inclusive education literature to relate the 'deficit way of understanding difference' to 'the ideology of individualism'8 (Walton and Bekker, 2013: 454):

\footnotetext{
${ }^{7}$ This is not the place for a detailed critique of these approaches. My sketchy remarks here are unlikely to persuade anyone that constructivism, for example, should be rejected. They merely serve to underline my misgivings about bestowing special status in education on a theoretical orientation that is deeply problematic. As Lotz-Sisitka claims, 'education has a critical role to play in preparing children to live in the world' (Lotz-Sisitka, 2009: 71; emphasis added). This arguably requires that those who so prepare children live there, too. Frankly, I cannot see constructivism making a substantial contribution to this preparation process.

${ }^{8}$ There has also been a lot of critique of research that explores individual experiences of disability. For example, Michael Oliver distinguishes between the individual and the social model of disability (Oliver, 1990; Oliver, 2004). He rejects the individual (or 'medical') approach because it locates the 'problem' in individual deficit and sees its causes as 'stemming from the functional limitations of psychological losses which are assumed to arise from disability' (Oliver, 1990: 3). It therefore, he claims, does not take into account the structural (economic, environmental and cultural) exclusions that people with disabilities face. The argument is that making disability a personal or individual tragedy, requiring individual intervention, obviates the need to consider disabling practices and attitudes in society (or the classroom) as a whole. Zach McCall and Thomas Skrtic (2009) contend that collective action against oppression is forestalled by a focus on individual 'problems'. It is perhaps ironic that Oliver's own approach is rather exclusive and judgemental. For example, he states that he does 'not intend to engage with the disapproving analyses that have been offered from those outside the [Disability Studies] Movement or in other parts of the academy' (Oliver, 2004:18). His point that 'the cultural environment in which we all grow up usually sees impairment as unattractive and unwanted' (p. 4) certainly deserves to be taken seriously. Nevertheless, while he may be correct in stating that 'parents' feelings towards, and treatment of, a child born with an impairment are dependent upon what they have learned about disability from the world around them' (p. 4), the following conclusion appears to be counter-intuitive, to say the least: "people who acquire impairment later in life have already been immersed in the personal tragedy viewpoint and it is not therefore surprising that many of these individuals find it difficult to know how to respond in any other way' (p. 5). So, to view impairment acquired later in life as a personal tragedy is mistaken? And the disabled who do so view their own condition are wrong? Oliver
} 
Individualism assumes that if children work hard enough and apply themselves they should be successful. This shifts the blame for lack of school success onto the individual child as either being 'unable' to succeed given an inner deficit or 'unwilling' to succeed in terms of effort and application. (Ibid.)

This characterisation of individualism seems to be mistaken. In fact, individualism by its very nature takes difference and individual capability seriously and disavows the deficit conception highlighted above. After all, disabled children (for example) do not constitute a faceless class: they are individuals, with varying needs and abilities..$^{9}$ A relevant and legitimate target would, rather, be performativity in education, which seems to have the bureaucratic and pernicious streak correctly targeted above.

Finally, providing a list of personal features or characteristics of educators who are capable of enabling epistemological access ${ }^{10}$ does not yield an explanation of why what these educators are mediating is (ipso facto) epistemological access. The challenge, then, would be to match the virtues of the inclusive, responsive teacher and the different ways in which and levels (for example, of difficulty and complexity) at which she works with and presents knowledge, how she thinks about, orders and sequences the knowledge she teaches, and the ways in which she works with the knowledge of others.

\section{Epistemic Parentalism}

Assuming responsibility for one's own beliefs is only one concern among many in epistemology. Another concerns responsibility for the beliefs of others, through teaching, selection and control. This involves what Alvin Goldman calls 'epistemic paternalism' (Goldman, 1992). It refers to the kind of knowledge, information or communication control that occurs in education and law and in various other kinds of social enterprises and relations. It means that certain kinds of information are often withheld or kept from people, for the benefit of the recipient of knowledge or information (for example, the learner). Goldman draws an analogy with parents who keep dangerous toys or other articles away from children, or who decide not to expose children to certain types of situation. A similar impulse, he says, is at work with shielding children, learners or people generally from certain facts or types of information. In what follows, I prefer to speak of 'parentalism' rather than 'paternalism'. For many, the latter has generally derogatory associations. Not only is it usually assumed to involve taking care of others while limiting

seems to proceed by way of bald assertion here. In fact, there seems to be a false dichotomy at work in his binary distinction. Focusing exclusively on the social model of disability may entail losing sight of the individual who is so disabled. It is not a matter of locating the 'problem' of disability in the individual but rather of individual recognition, of nurturing a sense of belonging in the individual and making sure that s/he does indeed 'belong'. Walton agrees that 'inclusion has to be about an educational responsiveness to individuality', but also thinks that 'when individual differences are made a major focus, teachers cannot imagine that they can teach more than one child at a time' (Walton, personal communication).

${ }^{9}$ Nussbaum endorses law's 'focus on protecting what most urgently needs protection: the claim of stigmatised children to be seen, and educated, as individuals' (Nussbaum, 2006: 210). Keith Lewin (2007: 34) claims, similarly, that

characteristics of individual learners are important. Their dispositions, capabilities and agency affect motivation to learn, application to learning activities, and learning outcomes. The more child centred basic education is, the more important it will be to understand what learners bring to schools, and how school processes address learning needs that may take very different forms for different individuals. Sustained participation depends on realistic accommodations of learners characteristics. Older children in particular acquire individual agency which shapes demand, participation and the extent to which meaningful learning takes place.

${ }^{10}$ Educators 'who demonstrate pedagogical sensitivity and tact' 'show empathy' (i.e., they 'try to understand the learner's point of view'; they 'have a positive view of others' (i.e., they 'demonstrate trust and confidence in the worth, ability and capacity for growth, development and learning of the learners'); they 'have a positive view of self' (i.e., they 'see themselves as capable and have a quiet sense of confidence'); they demonstrate 'authenticity' (i.e., they 'are genuine and real in their interactions with learners'); they 'have a meaningful purpose and vision' (i.e., they 'are committed to helping all learners to reach their potential'); and they 'are sensitive and perceptive of the needs of others' (Bekker, 2013: 477). 
their freedom and responsibility, but it also suggests a social order in which the father is the bearer of formal authority within the family. ('Maternalism' might go some way towards correcting the explicit androcentrism here, in its acknowledgement of informal, crucial and usually invisible familial authority, but it has a similarly gender-specific connotation.)

Goldman begins by saying that the so-called 'requirement of total evidence' (p. 209) may be unacceptable. 'Adequate evidence' concerns the amount of evidence or justification required for knowledge. One of the chief foci in epistemology is on the person who makes knowledge-claims - be it an educator or a learner - who tries to collect as much evidence as possible. Evidence is necessary to ensure the 'grounding' of our beliefs. Yet, Goldman's concern is to show that there may be reasons for doubting the desirability of the 'requirement of total evidence'.

Usefully for present purposes, Goldman chooses to illustrate epistemic parentalism with examples from the realm of education. In particular, he mentions curriculum selection. Curricular materials are selected by school personnel at various levels; not only by educators, but also by boards of education and principals. What is involved in curriculum selection? Epistemic parentalism is concerned not only with the relevance, suitability and verity of what is taught but also with the level of cognitive and emotional ability and maturity of the learners. Most pertinent to this discussion, learners are not exposed to all possible views or ideas on a given subject. Not only are they generally exposed only to materials that are relevant and appropriate to their level of understanding, but opinions that are regarded as false or indefensible are also withheld by current educational authorities.

Goldman cites the example of teaching creationism in biology or other science classes. The argument he considers is that experts on science should be allowed to decide that creationism is, unlike the theory of evolution, not a serious contender in terms of scientific theory and should not be taught in science classes. Parents and learners are, generally, not the kinds of authority who need to be consulted in this regard: that is, with respect to promotion of truth and avoidance of error.

Wondering about the need for parentalistically motivated epistemic constraints, Goldman asks whether epistemic parentalism is 'really warranted' (p. 214). A related question is, 'Is epistemic [parentalism] desirable in terms of promoting truth and avoiding error?' (pp. 214-215, 220) Logically speaking, epistemic parentalism is not necessary for education to occur. We could at least conceive of a situation where everything is taught indiscriminately, with little or no regard for its relevance, suitability and verity - a situation that nonetheless yields some kind of educational value. The more interesting question is whether epistemic parentalism is defensible - even desirable. The short answer seems to be, notwithstanding errors that are sometimes made in controlling knowledge and information, even with the best of intentions, that it should be practiced. Since none of us can reasonably hope to assess all evidence for all these personally, we often depend on the authority of others, so 'epistemic [parentalism] is frequently necessary and sometimes epistemically desirable' (p. 220). After all, it is practiced for the benefit of learners. This explains why a second kind of knowledge or information control, known as defensive teaching11, is undesirable: it occurs in the interest not of learners but, putatively, of educators themselves, or for reasons of safeguarding the status quo (as does indoctrination, for that matter).

Goldman points out that epistemology has traditionally assumed that all those working with knowledge and justification have the same cognitive resources, skills and opportunities, and that they operate without time constraints and the like. This is an idealised setting, he contends, which is endorsed neither by common sense nor by common experience.

[In] settings marked by different levels of expertise, by different opportunities for information gathering, by different levels of cognitive maturity and training, and by severe time constraints,

\footnotetext{
${ }^{11}$ Lori McNeil (1986) refers to 'fragmentation', 'mystification' and 'omission' as strategies in defensive teaching, none of which benefit or are even meant to benefit learners. 'Fragmentation', refers to 'the reduction of any topic to fragments or disjointed pieces of information' (McNeil, 1986: 167), in other words to lists. 'Mystification' is a further example. 'Teachers often [try] to surround a controversial or complex topic with mystery in order to close discussion of it' (p. 169). When they mystify 'a topic, they [make] it appear very important but unknowable' (p. 169). This strategy, like that of 'omission' (which extends 'beyond current topics to include ... controversial sides of topics', as well as viewpoints with which teachers disagree; p. 173), is frequently accompanied by a more or less explicit reference to students' ignorance or lack of maturity, and to divulge any further information would be akin to 'casting pearls before swine'.
} 
idealized principles of communication do not apply. A social epistemology for the real world needs to take these constraints into account. (p. 224)

This is especially pertinent with regard to learners living with various kinds of disability. Epistemic parentalism needs to take seriously the positions, perspectives and experiences of those who live with impairments in a society where impairment is not considered the norm but is seen, rather, as 'unattractive and unwanted' (Oliver, 2004: 4). The trick of course, as Claudia Schumann (2016: 7) points out, is not to replace

the rightfully criticized "view from nowhere" of a supposedly neutral epistemic subject with the equally uninhabitable "view from everywhere" of infinitely differentially embodied, situated, and interested knowers. Insofar as the infinite internally differentiated perspectives are all placed on equal par with each other, we run the danger of not having any criterion available to judge the validity of knowledge claims raised from any single perspective.

This may help explain why parentalism remains epistemically warranted. A defensible parentalism that takes on the epistemic positions of the impaired will be likely to reflect a more accurate picture of social reality than an approach that assumes an idealised setting, in Goldman's sense. I next turn to the idea of epistemic justice.

\section{Epistemic Justice}

Broadly, epistemic justice refers to the fair and equal distribution of epistemic benefits and burdens: it involves due acknowledgement of individuals as knowers with corresponding rights and obligations. In her influential account of epistemic injustice, Miranda Fricker distinguishes between two types of epistemic justice, testimonial and hermeneutical justice. Fricker refers to them as hybrid virtues (in that they both have an intellectual and an ethical component) that serve to countervail or prevent epistemic (i.e., respectively, testimonial and hermeneutical) injustice. 'Epistemic injustice', Fricker argues, 'is a distinct kind of injustice'. She distinguishes between two kinds, 'testimonial injustice' and 'hermeneutical injustice', each of which consists, 'most fundamentally, in a wrong done to someone specifically in their capacity as a knower' (Fricker, 2007: 1; see also p. 21).

Testimonial injustice occurs when prejudice causes a hearer to give a deflated level of credibility to a speaker's word; hermeneutical injustice occurs at a prior stage, when a gap in collective interpretive resources puts someone at an unfair disadvantage when it comes to making sense of their social experiences. (p. 1)

Central to her analysis is the notion of (social) 'power', which Fricker defines as 'a socially situated capacity to control others' actions' (p. 4; see also p. 13). Power works 'to create or preserve a given social order', and is displayed in various forms of enablement, on the one hand, and disbelief, misinterpretation and silencing, on the other. It involves the conferral on certain individuals or groups, qua persons of that kind, 'a credibility excess' or 'a credibility deficit' (p. 21). The primary characterisation of testimonial injustice, according to Fricker, 'remains such that it is a matter of credibility deficit and not credibility excess' (ibid.). This is certainly plausible, although we can think of instances where credibility excess is disadvantageous: an overburdened teacher or lecturer being asked questions by his students that call for a more specialist training. Similarly, promoting someone to a position (e.g. through affirmative action) for which they are not equipped, simply to rectify past wrongs, may be argued to involve epistemic harm.

Fricker's interest resides specifically with 'identity power' and the harms it produces through the manifestation of 'identity prejudices'. The latter are responsible for denying credibility to, or withholding it from, certain persons on the basis of their being members of a certain 'social type' (ibid.). Thus, testimonial injustice involves rejecting the credibility of their knowledge claims, while hermeneutical injustice involves a general failure of marshalling the conceptual resources necessary for understanding and interpreting these knowledge claims. The result is that these people are hindered in their self-development and in their attainment of full human worth: they are 'prevented from becoming who they are' (p. 5). In white patriarchal societies, these 'epistemic humiliations' (p. 51) ${ }^{12}$ carry the power to destroy a would-be (black or female) knower's confidence to engage in the trustful

\footnotetext{
${ }^{12}$ Fricker borrows the notion of epistemic humiliation from Simone de Beauvoir.
} 
conversations (pp. 52-53) that characterise well-functioning epistemic communities. As Fricker suggests, they can 'inhibit the very formation of self' (p. 55). Although they are experienced (and may be performed) individually, testimonial and hermeneutical injustice constitute not only individual harms: they originate within a social fabric of which the biases and prejudices that enliven and perpetuate them are a characteristic part. Contesting such injustices and harms, according to Fricker, requires 'collective social political change' (p. 8).

In order to bring about such change, what is required at a testimonial level is 'reflexive awareness of the likely presence of prejudice', and this 'anti-prejudicial virtue is the virtue of testimonial justice' (pp. 91-92). Testimonial justice, says Fricker, is 'both ethical and intellectual in character, at once a virtue of truth and a virtue of justice' (p. 124). Thus, apart from being able to rely on the competence and sincerity of speakers (p. 72), and apart from sensitivity (p. 72) and empathy (p. 79), 'hearers need dispositions that lead them reliably to accept truths and to reject falsehoods' (p. 115). However,

there is no guarantee that epistemic and ethical ends will harmonize. If some down-trodden schoolteacher is told in no uncertain terms by the unscrupulous head teacher that when the school inspector visits the classroom, he must ask the pupils a question and make sure that he picks from among the sea of raised hands someone who will come out with the right answer. This epistemic aim might be best served by a policy that is not remotely just. It might be best served, for instance by picking a pupil who, notoriously, always gets her big brother to text her the answers on her mobile. (p. 126)

'Hermeneutical justice, like testimonial justice, is a hybrid virtue' (p. 174), says Fricker. What it is meant to counteract is hermeneutical injustice - which occurs when (members of certain) groups or communities lack the hermeneutical tools to make sense of their own social experience (p. 146). 'For something to be an injustice, it must be harmful but also wrongful, whether because discriminatory or because otherwise unfair' (p. 151). When there is unequal 'hermeneutical participation with respect to some significant areas(s) of social experience, members of the disadvantaged group are hermeneutically marginalised' (p. 153). Fricker's account, of course, raises the question whether there could be hermeneutical self-marginalisation. Fricker appears to deny this:

Hermeneutical marginalisation is always socially coerced. If you simply opt out of full participation in hermeneutical processes as a matter of choice ..., then you do not count as hermeneutically marginalised - you've opted out, but you could have opted in. Hermeneutical marginalisation is always a form of powerlessness, whether structural or one-off. (p. 153)

Yes, one might respond, but one can be responsible for one's powerlessness. It would seem to follow that hermeneutical injustice and hermeneutical marginalisation are not identical, insofar as the latter can be seen to include self-marginalisation.

Louise Antony suggests the adoption of 'epistemic affirmative action' by men as a 'working hypothesis that when a woman, or any member of a stereotyped group, says something anomalous, they should assume that it's they who do not understand, not that it is the woman that is nuts' (Antony, 1995: 89; quoted in Fricker, 2007: 171). By contrast, Fricker does not believe a policy of epistemic affirmative action across all subject matters to be justified: "the best way to honour the compensatory idea is in the form of a capacity for indefinitely context-sensitive judgement - in the form ... of a virtue' (Fricker, 2007: 171). At what point, then, can a white man judge a woman, or any member of a stereotyped group, to be 'nuts' - if ever? Does epistemic justice require me, as a matter of course, to reserve judgement, to keep 'an open mind as to credibility' (p. 172)? As I have indicated above, if 'credibility deficit' is a matter of epistemic injustice, then why should 'credibility excess' (giving previously 'epistemologically humiliated' people or groups lots of credibility) not also constitute epistemic harm? More fundamentally, surely there is a difference between criticising someone's view on the mere grounds that she is black, or a woman, and criticising the views held or expressed by someone, who happens to be black or a woman, on the grounds of faulty or fallacious reasoning. Nonsense is not culturally, racially or sexually specific. Indeed, although she gestures in the direction of a basic 'do no harm' principle (p. 85), Fricker herself insists that a "vulgar" relativist' resistance to passing moral judgment on other cultures 'is incoherent' (p. 106).

Given how prejudice affects various levels of credibility, this discussion raises the question whether the idea of epistemic (in-)justice (which, after all, in Fricker's analysis refers to the epistemic situation of women and blacks in a world dominated by men and whites) is at all relevant to inclusion of those with impairments. (That it is relevant to the situation of foreign nationals is surely not in doubt.) 
Testimonial justice appears as an original virtue of both justice and truth. Applied to the case of inclusion, it expresses the idea that the influence of a possible identity prejudice (in this case, against a person with cognitive disability or impairment) on the part of the (non-impaired) hearer has been recognised and corrected. Hermeneutical justice manifests itself in the reflective-critical sensitivity of the (non-impaired) hearer to any reduced understanding (or any failure to comprehend) incurred by the speaker (in this case, the person with cognitive disability) because of a gap in the collective hermeneutical resources. In other words, the hearer is aware of the fact that the speaker's apparent lack of understanding is 'a function of a collective hermeneutical impoverishment, and he adjusts or suspends his credibility judgement accordingly' (Fricker, 2007: 7).

To take a relevant example of hermeneutical injustice suggested by Emily Robertson: having long been excluded from the development of an available framework for articulating their experience, "recently people with intellectual disabilities have rejected the term "retarded" as a slur although the field of "mental retardation" has used it for years' (Robertson, 2013: 302). This indicates, Robertson asserts, that inclusion of the experiences and perspectives of marginalised groups in knowledge production can change the conceptual landscape in epistemically fruitful ways' (ibid.).

\section{$5 \quad$ Further Questions and Concluding Thoughts}

This article has been concerned in the main with certain epistemological considerations pertaining inclusive education. What possibilities for learning and the acquisition of knowledge exist for those with cognitive and physical impairments? Access to institutions of learning is not identical to epistemological access. An additional consideration is that learning possibilities, as well as the mediation and acquisition of knowledge, differ from person to person. Given that no-one can participate or be included everywhere or claim unlimited access for oneself, should one nonetheless be able to determine to what one has access? While perhaps desirable this is clearly utopian. Especially in cases of limited autonomy and selfdetermination a certain knowledge and information control is arguably both necessary and justified. In other words, the young and the cognitively impaired are not given unlimited access to knowledge and information. (Nor are any of us, for that matter, under any and all circumstances.)

The controlled transfer of knowledge and information raises the question of epistemic justice. How ought one to accommodate the knowledge claims and the epistemic and cognitive abilities of those with relevant impairments? Under what circumstances can one speak of knowledge here? What would be the basis for inclusion within a knowledge community? Without being able to provide a comprehensive analysis here, I suggest that a context-sensitive realism offers plausible responses to these questions. It is concerned with a normative account: it deals with processes that ought or ought not to be called 'knowledge' (Horsthemke, 2013). In other words, 'knowledge' is not ambiguous between various concepts of knowledge. What constitutes knowledge does not fluctuate with differences in people's cognitive abilities or with what their constructs, 'regimes' or 'politics' are. It does acknowledge that people do not have the same cognitive resources, abilities and opportunities. They do not all act or operate in the absence of time constraints. Their situations are characterised by different levels of expertise, by different opportunities to access and gather information, by different levels of cognitive ability, maturity and training, and by considerable disparities in time constraints. This insight permits us to talk of different levels of knowledge, without implying relativism. It is not the case that 'anything goes', epistemologically. The knowledge in question remains characterised by the pursuit of truth and the avoidance of error. A relevantly disabled person's claim constitutes 'knowledge' only if it is true. The same - obviously - goes for the claims of those without pertinent disabilities. Truth does not vary according to particular individuals, social or ethnic groups, or different cultures. This explains why we, as educators, are more lenient in some cases than in others, but our leniency does not extend to condoning untruths or falsehoods.

Acknowledgement. This article was written as a contribution by the sub-project on inclusion and educational justice to the joint project "Inklusives Leben und Lernen in der Schule" ("Inclusive Living and Learning in the School"), which is based at KU Eichstätt-Ingolstadt and sponsored by the Freisinger Bischofskonferenz, Germany. 


\section{References}

1. L. Antony (1995), "Sisters, please, I'd rather do it myself: A defense of individualism in feminist epistemology," Philosophical Topics, vol. 23, no. 2, pp. 59-94.

2. T. Bekker (2013), "Ensuring epistemological access," in Education studies, edited by K. Horsthemke, P. Siyakwazi, E. Walton and C. Wolhuter, pp. 463-485. Cape Town: Oxford University Press South Africa.

3. G. Delanty (1997), Social science: Beyond constructivism and realism. Buckingham: Open University Press.

4. T.M. Duffy and D. Cunningham (1996), "Constructivism: Implications for the design and delivery of instruction," in Handbook of research for educational communications and technology, edited by D. Jonnasen, pp. 170-198. Mahwah/NJ: Lawrence Erlbaum Associates.

5. M. Foucault (1984), "Truth and power," in The Foucault reader, edited by P. Rabinow. New York: Pantheon Books.

6. M. Fricker (2007), Epistemic injustice: Power and the ethics of knowing. Oxford: Oxford University Press.

7. A.I. Goldman (1992), "Epistemic paternalism: Communication control in law and society," in Liaisons: Philosophy meets the cognitive and social sciences, pp. 209-225. Cambridge/MA: MIT Press.

8. A. Gutmann (1987), Democratic education. Princeton: Princeton University Press.

9. A. Gutmann (2009), "Educating for individual freedom and democratic citizenship: In unity and diversity there is strength," in The Oxford handbook of philosophy of education, edited by H. Siegel, pp. 409-427. Oxford \& New York: Oxford University Press.

10.K. Horsthemke (2013), "Knowledge and education," In Education studies, edited by K. Horsthemke, P. Siyakwazi, E. Walton and C. Wolhuter, pp. 338-420. Cape Town: Oxford University Press South Africa.

11.K.M. Lewin (2007), "Improving access, equity and transitions in education: Creating a research agenda," Create Pathways to Access, Research Monograph No 1, June. Available: http://www.createrpc.org/pdf_documents/PTA1.pdf

12.H. Lotz-Sisitka (2009), "Epistemological access as an open question in education," Journal of Education, vol. 46, pp. $57-79$.

13.Z. McCall and T.M. Skrtic (2009), "Intersectional needs politics: A policy frame for the wicked problem of disproportionality," Multiple Voices for Ethnically Diverse Exceptional Learners, vol. 11, no. 2, pp. 3-23.

14.L.H. McNeil (1986), Contradictions of control: School structure and school knowledge. New York \& London: Routledge \& Kegan Paul.

15.K. Merz-Atalik (2015), "Inklusive Bildung in einer leistungsorientierten Gesellschaft - Von der Utopie zur Wirklichkeit," presentation as part of the series "mittwochsBILDUNG", Gemeinnützige, Gesellschaftshaus Lübeck, 4 November.

16.W. Morrow (2007). Learning to teach in South Africa. Cape Town: HRSC Press.

17.W. Morrow (2009), Bounds of democracy: Epistemological access in higher education. Cape Town: HSRC Press.

18.M. Nussbaum (2006), Frontiers of justice: Disability, nationality, species membership. Cambridge/MA: BelknapHarvard.

19.M.J. Oliver (1990), "The individual and social models of disability," paper presented at the Joint Workshop of the Living Options Group and the Research Unit of the Royal College of Physicians on 'People with Established Locomotor Disabilities in Hospitals', 23 July. Available: http://disability-studies.leeds.ac.uk/files/library/Oliverin-soc-dis.pdf

20.M.J. Oliver (2004), "The social model in action: If I had a hammer," In Implementing the social model of disability: Theory and research, edited by C. Barnes and G. Mercer, pp. 18-31. Leeds: The Disability Press.

21.J. Potter (1996), Representing reality: Discourse, rhetoric and social construction. London: Sage.

22.J. Rawls (1971), A theory of justice. Oxford: Clarendon Press.

23.J. Rawls (1996), Political liberalism. New York: Columbia University Press.

24.V. Richardson (2003), "Constructivist pedagogy," Teachers College Record, vol. 105, no. 9, pp. 1623-1640.

25.E. Robertson (2013), "The epistemic value of diversity," Journal of Philosophy of Education, vol. 47, no. 2, pp. 299-310.

26.C. Schumann (2016), "Knowledge for a common world? On the place of feminist epistemology in a philosophy of education," Education Sciences, vol. 6, no. 10, pp. 1-13. Available: www.mdpi.com/2227-7102/6/1/10/pdf 
27.K. Stojanov (2011), Bildungsgerechtigkeit: Rekonstruktionen eines umkämpften Begriffs. Wiesbaden: Springer VS.

28.K. Stojanov (2015), "Inklusion und Bildungsgerechtigkeit," concept paper as part of the joint project "Inklusives Leben und Lernen in der Schule", KU Eichstätt-Ingolstadt, 28 April.

29.E. Von Glasersfeld (2000), "Problems of constructivism," in Radical constructivism in action: Building on the pioneering work of Ernst Von Glasersfeld, edited by L.P. Steffe and P.W. Thompson, pp. 1-9. New York \& London: Routledge Falmer.

30.E. Walton and T. Bekker (2013), "Pedagogy and inclusion," in Education studies, edited by K. Horsthemke, P. Siyakwazi, E. Walton and C. Wolhuter, pp. 440-462. Cape Town: Oxford University Press South Africa.

31.E. Walton (2013), "Responsive teaching," in Education studies, edited by K. Horsthemke, P. Siyakwazi, E. Walton and C. Wolhuter, pp. 486-510. Cape Town: Oxford University Press South Africa.

32.M. Windschitl (1999), "A vision educators can put into practice: Portraying the constructivist classroom as a cultural system," School Science and Mathematics, vol. 4, pp. 189-196.

33.M. Windschitl (2002), Framing constructivism in practice as the negotiation of dilemmas: An analysis of the conceptual, pedagogical, cultural, and political challenges facing teachers. Review of Educational Research, vol. 72, no. 2, pp. 131-175. 